\title{
Peran Orang Tua Terhadap Hasil Belajar Siswa Pada Pembelajaran Daring
}

\author{
Zulfatun Na'im', Eva Luthfi Fakhru Ahsani \\ ${ }^{1,2}$ Fakultas Tarbiyyah, PGMI, Institut Agama Islam Negeri Kudus \\ Email: zulfatunnaim3052@gmail.com
}

\begin{abstract}
ABSTRAK
Artikel ini bertujuan untuk mengetahui: 1) bagaimana peran Orang Tua terhadap hasil belajar siswa?, 2)bagaimana peran Orang Tua dalam pembelajaran daring?, 3)Apa upaya yang dilaksanakan oleh Orang Tua dalam meningkatkan hasil belajar siswa dalam pembelajaran daring?. Orang Tua adalah salah satu orang yang sangat bertanggung jawab dalam proses pendidikan anak. Peran aktif orang tua dalam masa pandemi Covid-19 ini dengan pelaksanaan pembelajaran daring akan memberikan pengaruh terhadap hasil belajar siswa. Metode penelitian yang digunakan dalam penelitian ini adalah metode penelitian Kualitatif dan dalam pengumpulan data menggunakan metode Fenomenologi dan subjek penelitian adalah Orang Tua. Dari penelitian yang telah dilaksanakan maka hasil dari penelitian tersebut adalah: Peran Orang Tua terhadap hasil belajar siswa sangat penting, dengan adanya tanggung jawab dari orang tersebut maka hasil belajar siswa akan berpengaruh khususnya hasilnya belajar yang berkaitan dengan Afektif dan Psikomotorik, Perang Orang Tua dalam pembelajaran daring di masa pandemi Covid-19 sangat berpengaruh dan sangat penting, dengan adanya peran orang tua dalam pembelajaran daring ini, maka anak akan menyelesaikan tugas yang telah diberikan, dan kemampuan anak tetap berkembang walaupun tidak dengan Guru pendampingnya. Usaha yang dilakukan Orang Tua yaitu selalu untuk memotivasi dan memberikan semangat agar anak mampu untuk melaksanakan pembelajaran daring.
\end{abstract}

Keywords : Peran Orang Tua; Hasil Belajar; Pembelajaran Daring.

\begin{abstract}
This article aims to find out: 1) what is the role of parents on student learning outcomes? 2) what is the role of parents in online learning ?, 3) What are the efforts made by parents in improving student learning outcomes in online learning?. Parents are one of the people who are very responsible in the process of children's education. The active role of parents during the Covid-19 pandemic by implementing online learning will have an impact on student learning outcomes. The research method used in this research is qualitative research methods and in data collection using the phenomenological method and the research subjects are parents. From the research that has been carried out, the results of this study are: The role of parents on student learning outcomes is very important, with the responsibility of that person, student learning outcomes will affect especially learning outcomes related to affective and psychomotor, parental war in learning online during the Covid-19 pandemic is very influential and very important, with the role of parents in this online learning, the child will complete the task that has been given, and the child's ability to continue to develop even though not with the accompanying teacher. The efforts made by parents are always to motivate and encourage children to be able to carry out online learning.
\end{abstract}

Keywords: The role of parents; Learning outcomes; Online Learning.

(C) 2021 Zulfatun Na'im, Eva Luthfi Fakhru Ahsani Under the license CC BY-SA 4.0 


\section{PENDAHULUAN}

Pendidikan adalah usaha sadar dan terencana dalam rangka untuk mewujudkan suasana belajar dan proses pembelajaran sehingga peserta didik secara aktif dapat mengembangkan potensi yang ada di dalam diri peserta didik sehingga mampu memiliki kekuatan, baik kekuatan spiritual keagamaan, pengendalian diri, kepribadian, kecerdasan, akhlak mulia, dan keterampilan yang diperlukan untuk diri peserta didik, masyarakat bahkan untuk bangsa dan negara. (Shiyana, 2014). Pendidikan Nasional memiliki fungsi untuk mengembangkan kemampuan dan membentuk watak dalam diri peserta didik serta membangun peradaban bangsa yang bermartabat dalam rangka untuk mencerdaskan bangsa, sehingga memiliki tujuan untuk mengembangkan potensi dalam diri siswa sehingga menjadi manusia yang beriman dan bertakwa kepada Tuhan Yang Maha Esa, memiliki akhlak mulia, sehat berilmu, cakap, kreatif, mandiri dan menjadi Negara yang demokratis serta bertanggung jawab. UU Sisdiknas No.20 (2003) (RI, n.d.).

Siswa akan mampu untuk tumbuh dan berkembang menjadi pribadi yang utuh dan sempurna apabila didukung dengan pendidikan yang baik. Dalam rangka pengembangan kemampuan siswa untuk mudah dalam menerima berbagai macam ilmu pengetahuan, maka dibutuhkannya suatu proses pembelajaran yang harus dilakukan sebaik dan semaksimal mungkin dalam proses pendidikan. Pendidikan memberikan kontribusi yang sangat besar terhadap kemajuan suatu bangsa. Proses perkembangan dan pertumbuhan pada diri anak dapat dilakukan di berbagai tempat yaitu baik disekolah atau di rumah masingmasing. Sekarang di Indonesia sedang dilaksanakan pembelajaran yang bersifat daring hal ini dikarenakan sedang ada Pandemi Dunia yaitu Corana atau sering disebut dengan Covid-19.

Corona Virus adalah jenis virus baru yang awal muncul di Wuhan Negara China, yaitu dipasar seafood Huanan. Penyakit ini ditimbulkan karena adanya penularan oleh hewan-hewan yang dijual dipasar seperti kelelawar, anjing, ular dan lain sebagainya. Virus ini dapat menyebar dan tertular melalui droplet (partikel) yaitu ketika manusia saling berinteraksi secara langsung (berkomunikasi). Secara perlahan virus ini menyebar ke seluruh dunia, termasuk di Negara Indonesia. Di Indonesia Virus Corona mulai muncul pada awal Maret 2020, secara perlahan-lahan virus ini menyebar di wilayah Indonesia. Jumlah 
kasus semakin meningkat menurut data per 10 Mei 2020 ini kasus positif Corona Di Indonesia mencapai 14.032, kasus sembuh 2.698 dan kasus meninggal mencapai angka 973. (Indonesia, 2020). Dengan tingginya kasus virus Covid-19 di Indonesia maka sesuai dengan Kepres Nomor 12 tahun 2020 tentang Penetapan Covid-19 sebagai bencana Nasional. Pusat, Keputusan Presiden KEPRES Nomor 12 Tahun (2020).

Semakin meningkatnya angka penyebaran Covid-19 di Indonesia, maka pemerintah Indonesia melakukan berbagai usaha untuk mencegah penularan Virus tersebut. Pemerintah Indonesia telah membentuk dan mengaktifkan Tim Gerak Cepat (TGC) yang ditugaskan di wilayah kekuasaan pintu masuk negara yaitu di wilayah bandara atau pelabuhan atau juga pos lintas batas darat Negara (PLBDN). Tim Gerak Cepat (TGC) terdiri dari petugas Kantor Kesehatan Pelabuhan (KKP), Imigrasi, Bea Cukai, Karantina Hewan dan unit lain yang releven di wilayah kekuasaan pintu masuk Negara yang memiliki perkiraan masuknya penyakit ke Indonesia. Pusat langkah dan upaya Pemerintah Indonesia dalam menangani dan menghadapi Virus Corona 2019 (2020).

Himbauan dari Presiden Joko Widodo untuk meminimalisir penyebaran Virus Corona, maka menghimbau agar seluruh warga Indonesia untuk bekerja, belajar dan beribadah di rumah. Yang kemudian ditindak lanjuti melalui surat edaran nomor 19 Tahun 2020 oleh Menteri Pendayagunaan Kerja Aparatur Sipil Negara yang berisi bahwa ASN dapat bekerja di rumah atau tempat tinggal, larangan adanya kegiatan tatap muka yang menyebabkan hadirnya banyak peserta atau kerumunan, maka pelaksanaannya untuk dibatalkan atau diundur. Pemerintah Pusat (2020).

Physical Distancing atau menjaga jarak fisik dengan orang lain menjadi hal yang sangat ditekankan oleh Presiden Joko Widodo untuk pencegahan dan penanganan virus Covid-19 di Indonesia. Pusat, Undang-Undang Nomor 6 (2019) Jarak fisik ini sangatlah penting untuk dilaksanakan oleh seluruh penduduk Indonesia yang tidak hanya berlaku ditempat umum saja, akan tetapi juga diberlakukan untuk seluruh keluarga di Indonesia begitu juga dengan dunia pendidikan.

Menteri Pendidikan dan Kebudayaan (Kemendikbud) Nadiem Makarim dalam rangka mengurangi penyebaran Covid-19 dalam dunia pendidikan maka menerbitkan Surat Edaran Nomor 4 tahun 2020 mengenai pelaksanaan pendidikan dalam Masa Darurat Coronavirus Deisease 
(Covid-19) yang didalamnya memuat ketentuan Ujian Nasional (UN) . Proses belajar dari rumah dilaksanakan dengan berbagai ketentuan : a) proses belajar dari rumah melalui model pembelajaran daring atau jarak jauh dilaksanakan dalam rangka untuk memberikan pengalaman belajar yang bermakna bagi siswa, tanpa ada rasa terbebani dengan adanya tuntunan untuk menuntaskan seluruh capaian kurikulum dalam rangka untuk kenaikan kelas atau kelulusan, b) proses belajar dari rumah dapat diutamakan pada pendidikan yang berkaitan dengan kecakapan hidup salah satunya yaitu mengenai pandemi Covid-19, c) aktivitas dalam proses belajar dan tugas pembelajaran dengan belajar dari rumah yang dapat dilakukan dengan cara yang bervariasi antar siswa, sesuai dengan minat dan kondisi dari masing-masing, termasuk juga harus mempertimbangkan kesenjangan akses atau fasilitas untuk mendukung proses belajar dari rumah, d) hasil dari aktivitas belajar dari rumah diberi umpan balik atau penelitian yang bersifat kualitatif dan berguna dari guru. Tanpa diharuskan memberi skor atau penilaian kuantitatif. Ketentuan Ujian Sekolah dalam rangka kelulusan. Ketentuan kenaikan kelas. dan Ketentuan adanya Penerimaan Peserta Didik Baru (PPDB), dana bantuan operasional sekolah atau bantuan operasional pendidikan. Pemerintah Pusat (2020). Maka seluruh siswa di Indonesia baik dari jenjang PAUD sampai SMA/SMK dan juga Mahasiswa diharuskan untuk melaksanakan pembelajaran dirumah secara online. Pembelajaran online bagi siswa merupakan hal yang baru.

Ditengah Karantina karena adanya pandemik dunia. Maka peran Orang Tua dalam proses pembelajaran sangatlah penting, hal ini dikarenakan Orang Tua harus menjalankan tugas sebagai guru untuk anak-anaknya, memperhatikan anak selama mengerjakan pekerjaan rumah, memberikan pembelajaran mengenai pentingnya menjaga kesehatan agar terbebas dari paparan Covid-19, memberikan perhatian dan pengawasan lebih agar anak merasa aman, nyaman dan tenang di tengah pandemi yang dapat mengganggu kesehatan mental anak. Sehingga orang tua perlu untuk meluangkan waktu lebih banyak untuk mendampingi anak. (Dede Rahmaida Nurlaeli \& Nunung Nurwanti, 2020) .

Orang Tua adalah penanggung jawab pertama dan utama dalam proses pendidikan anak-anaknya. Dimanapun anak tersebut belajar baik di lembaga formal, informal maupun non formal, peran orang tua dalam menentukan masa depan pendidikan anak-anaknya sangatlah penting. (Afni \& Jumahir, 2020). Peran aktif orang 
tua dalam pembelajaran dirumah akan memberikan pengaruh terhadap hasil belajar anak. Pencapaian hasil belajar merupakan nilai yang sangat menentukan prestasi bagi anak di sekolah. Sehingga sikap dan perilaku baik yang dimiliki oleh seorang anak dapat menjadi kebanggaan bagi dirinya sendiri dan orang tua dan dapat menjadi rancangan untuk masa depan untuk mencapai cita-cita yang diinginkan oleh anaknya. Selain itu dengan juga mempengaruhi terhadap keterampilan peserta didik, bahwa orang tua berperan untuk dapat memandu peserta didik memehami instruksi lisan dari tayangan video, da untuk tugas yang tertulis, orang tua dapet membantu peserta didik untuk menuliskan barus demi baris tugas yang yang diberikan oleh guru. (Ahsani \& Ningsih, 2020) . Hasil belajar yang telah dicapai oleh peserta didik adalah hasil dari prestasi yang ditimbulkan karena adanya faktor-faktor yang saling mempengaruhi faktor-faktor utama yang juga mampu mempengaruhi hasil belajar siswa yaitu faktor internal (faktor yang berasal dari dalam diri siswa) dan faktor eksternal (faktor yang berasal dari lingkungan keluarga, kematangan setiap individu, metode belajar, sumber belajar atau hal lain yang datang dari luar siswa). (Miranti et al., 2017).
Dari paparan diatas, peneliti mengamati bahwa peran orang tua itu sangat penting dalam rangka untuk peningkatan prestasi siswa berupa hasil belajar siswa di masa pandemi. Orang tua mempunyai peran yang utama dalam masa pandemi ini dikarenakan anak membutuhkan perhatian lebih dari orang tua saat berada di rumah, orang tua harus selalu memberikan motivasi, semangat dan selalu menemani di saat belajar agar anak tidak mengalami stress di tengah pandemi. Tulisan ini bertujuan untuk mendeskripsikan tentang perang penting orang tua terhadap hasil belajar siswa pada masa pandemi Covid-19.

Pada tulisan ini ada kesamaan dan perbedaan pada penelitian Dede Rahmaida Nurlaeli dan Nunung Nurwati yang berjudul "Kelekatan (Attachment) Ibu - Anak Di Tengah COVID-19", pada penelitian tersebut lebih menitik beratkan pada kelekatan Ibu dan anak di tengah Pandemi Covid-19. Sedangkan pada tulisan ini lebih menitik beratkan terhadap perang penting orang tua terhadap hasil belajar siswa dalam pembelajaran daring di masa pandemi Covid-19. Adapun titik persamaan penelitian Dede Rahmaida Nurlaeli dan Nunung Nurwati dengan mini riset ini terdapat pada pembahasan yang mengkritik tentang peran orang tua dalam proses 
pembelajaran siswa di masa pandemi Covid-19. Sementara itu, temuan penting yang ada pada tulisan ini yaitu mengenai perang orang tua terhadap hasil belajar siswa dalam pembelajaran daring. (Nurlaeli, 2020)

\section{METODE PENELITIAN}

Metode penelitian yang dilakukan dalam pelaksanaan penelitian ini yaitu menggunakan jenis penelitian kualitatif, yaitu penelitian yang lebih menekankan pada sikap realitas yang dapat terbangun secara sosial, adanya hubungan yang erat antara peneliti dan subjek yang akan diteliti, dan adanya tekanan situasi yang akhirnya menimbulkan adanya suatu penyelidikan. Pada penelitian ini peneliti lebih menitik beratkan pada kualitas hasil dari penelitian yang dilakukan yaitu penelitian yang mendalam terhadap permasalahan dan penyelesaian. Dalam penelitian ini peneliti menggunakan observasi non partisipatoris artinya bahwa peneliti tidak terjun langsung kedalam subjek yang menjadi kasus penelitian, akan tetapi dengan cara mengamati dari jarak jauh dan juga menggunakan metode penelitian fenomenologi yaitu jenis penelitian yang dilakukan dalam rangka untuk membuktikan adanya kebenaran-kebanaran yang terjadi disekitar subjek penelitian, kebenaran-kebenaran yang dibuktikan yaitu: kebenaran empiris yang terindra, kebenaran empiris yang masuk akal, kebenaran empiris etik dan kebenaran transendental.

Sifat penelitian yang dilakukan oleh peneliti ini bersifat mendalam, yaitu Peran Orang Tua Terhadap Hasil Belajar Siswa Dalam Pembelajaran Daring Pada Masa Pandemi Covid-19. Adapun studi kasus pada penelitian ini adalah Orang tua-Orang tua yang masih memiliki anak yang berusia SD/MI di Desa Prambatan Lor di Masa Pandemi Covid-19 tahun 2020. Dilihat dari segi analisisnya, maka penelitian ini bersifat kualitatif, yaitu mendalami terhadap permasalahan dan mencari solusi dari permasalahan yang telah diangkat, dan data yang disajikan dalam penelitian ini berbentuk kata-kata atau kalimat bukan dalam bentuk angka. Penelitian ini menggunakan pendekatan Observasi nopartipatoris yaitu, peneliti tidak ikut serta atau tidak ikut terjun langsung dalam pengamatan, dan hanya sekedar pengamatan dari jarak jauh. Dengan penggunaan pendekatan observasi Non Partisipatoris terhadap subjek kegiatan yang dilakukan oleh subjek dapat terlihat sedikit jelas untuk peneliti amati, diamati dari kegiatan anaknya dan perhatian dari orang tuanya mengenai tugas yang telah 
diberikan. Peneliti mengamati subjek sejak dari awal sejak adanya Covid-19 ini masuk ke Indonesia sehingga sekolah sejak PAUD, SD/MI, SMP/Mts, SMA/MA dan Universitas diliburkan, peneliti menggunakan penelitian fenomenologi berupa keadaan-keadaan yang nyata yang ada disekitar subjek. Dan untuk analisis data dalam hal ini penulis menggunakan analisis non statistik, yaitu data yang dianalisis itu berdasarkan isinya.

\section{HASIL DAN PEMBAHASAN}

\section{Hasil}

\section{Peran Orang Tua Terhadap Hasil Belajar Siswa Dalam Pembelajaran Daring}

Sebagai bagian dari salah satu upaya yang dilakukan untuk menghentikan penyebaran virus, maka pemerintah melakukan usaha untuk mengalihkan kegiatan pembelajaran yang awalnya dari sekolah kemudian diubah dengan pembelajaran di rumah masing-masing siswa. Agar kegiatan belajar dirumah tidak disalah artikan dengan siswa sebagai hari libur, maka siswa tetap diberi tugas-tugas pembelajaran agar mereka tetap merasa sedang dalam suasana belajar. Oleh sebab itu, maka Guru diharuskan untuk mampu mendesain tugas-tugas untuk siswa selama belajar di rumah dengan sebaik mungkin.
Banyaknya tugas dari Guru kepada peserta didik seringkai menjadi salah satu keluhan dalam pelaksanaan pembelajaran daring. Beban belajar peserta didik tentunya harus diperhitungkan, terukur, baik secara materi maupun waktu. Dengan pembelajaran daring ini diharapkan peserta didik tidak menjadi robot yang hanya selalu mengerjakan latihan soal yang banyak sekali tanpa mampu berpikir dalam level tinggi. Sehingga dalam hal ini, keluarga khususnya orang tua yang ada dirumah mempunyai peran atau andil yang penting dalam pelaksanaan pembelajaran siswa.

Sehingga dalam hal ini, Guru harus membangun komunikasi dengan orang tua siswa agar pelaksanaan pembelajaran secara daring (online) ini tetap dapat terlaksana secara baik dan hasilnya pun tidak terpaut jauh dengan pembelajaran yang dilaksanakan di sekolah (dikelas) dengan tatap muka. Selain itu juga, Guru juga harus mampu membawakan budaya belajar di sekolah ke dalam rumah (ruang keluarga) para peserta didik. Hal seperti inilah yang perlu adanya komunikasikan antara orang tua dan Guru. Para orang tua harus mampu memahami bahwa walaupun belajar di rumah, anak harus tetap berkonsentrasi pada saat proses pembelajaran berlangsung. Dalam hal inilah, dukungan orang tua itu sangat dibutuhkan. 
Proses pengerjaan tugas oleh siswa yang telah diberikan oleh Guru memang menghabiskan banyak waktu, biaya, dan juga energi. Sehari-hari siswa harus berada di rumah untuk menyelesaikan tugas yang telah diberikan oleh Guru dengan tepat waktu. Dengan adanya kegiatan tersebut, diharapkan para orang tua juga memahami bahwa sesungguhnya dukungan dan peran dari mereka sangat dibutuhkan sekali oleh anak dalam proses pembelajaran seharihari.

Kemampuan untuk membagi waktu dan menyelesaikan masalah secara tepat juga dapat menjadi salah satu efek dalam keberhasilan siswa terhadap tugas yang telah diberikan oleh Guru. Apabila tidak diberikan perhatian dari Orang Tua. maka siswa tidak akan bisa membagi waktu dan menyelesaikan tugas dengan baik. Terkadang juga orang tua masih belum memahami karakter anaknya sendiri, orang tua dapat mengetahui karakter dari anaknya ketika anak sedang mengerjakan tugas yang telah diberikan oleh Guru. Hal ini, diharapkan orang tua mampu memahami bahwa pendidikan yang berawal dari keluarga itu sangat penting dan sebagai pendidikan pertama dalam pembentukan karakter anak.

Orang tua bukanlah seseorang yang hanya berfungsi sebagai pemenuhan kebutuhan materil anak, akan tetapi orang tua juga memenuhi kebutuhan immaterialnya (perhatian kepada anak). Kesibukan dari orang tua dapat menjadi boomerang yang besar dalam keluarganya, jika tidaknya adanya pendampingan yang baik dari orang tua kepada anak, maka hasil belajar di bangku sekolah tidak akan dapat berbekas dan bermakna di dalam diri siswa dan dalam kehidupan bermasyarakat. Pengawasan dan pengendalian anak usia sekolah sangatlah membutuhkan peran dari orang tua. Sebab, kemampuan akademis yang mencakup seluruh aspek karakter anak dari pengetahuan kognitif hingga jiwa dan raga, tidaklah hanya tanggung jawab guru yang ada disekolah. Dengan adanya perang orang tua dalam proses pembelajaran akan menjadi kunci bagi keberhasilan peserta didik untuk menjadi Sumber Daya Manusia yang unggul. (Setiawan, 2020).

Dalam pelaksanaan pembelajaran daring untuk mencegah penyebaran virus Covid-19 maka banyak guru yang menggunakan aplikasi WhatsApp dengan membuat Grup kelas yang didalamnya terdiri dari anggota kelas dan orang tua siswa, penggunaan aplikasi WhatsApp dalam pembelajaran daring dikarenakan mudah untuk digunakan, dan banyak orang tua yang menggunakan aplikasi tersebut dan tidak memerlukan biaya yang banyak. 
Selain itu, dengan penggunaan aplikasi ini Guru dapat mengirimkan pesan dan gambar kepada Orang tua murid. Guru mengirimkan video berupa video yang mengenai materi pembelajaran yang akan dilaksanakan. Dengan penggunaan aplikasi ini juga Guru dapat melaksanakan interaksi dengan Orang tua murid, sehingga walaupun tidak dapat bertatap muka dengan peserta didik, Guru masih tetap bisa mengetahui perkembangan dari peserta didik tersebut.

Proses pelaksanaan pembelajaran yang dilakukan oleh Guru dalam rangka untuk meningkatkan kemampuan siswa yaitu dengan cara memberikan dan mengirimkan soal melalui ponsel atau laptop peserta didik atau orang tuanya. Kemudian peserta didik tinggal mengerjakannya. Hasil dari pekerjaan atau tugas tersebut kemudian dikirim kembali ke Guru melalui aplikasi WA atau pada saat masuk sekolah. Selain dengan memberikan soal, Guru juga bisa memberikan atau mengirimkan Video yang berkaitan dengan materi yang akan dipelajari sesuai dengan jadwal pelajaran, dengan pengiriman video ini oleh Guru maka peserta didik juga akan lebih tertarik dibanding dengan memberikan soal saja.

Dengan penggunaan aplikasi WhatsApp ini apabila dilihat dari kelemahan yang sudah disebutkan, maka peran orang tua sangat penting dalam pelaksanaan pembelajaran. Khususnya untuk kelas rendah (kelas 1-3), maka harus ada pengawasan yang sangat ketat dalam pelaksanaan pembelajaran, karena apabila anak dibiarkan tanpa ada pengawasan khusus dari orang tua maka siswa akan bermain game dari hp tersebut.

Pelaksanaan pembelajaran dengan daring ini banyak Guru yang mengirimkan tugas kepada siswa, tidak banyak orang tua yang selalu memperhatikan tugas yang sudah dikirimkan ke Grup WhatsApp. Terkadang orang tua acuh tak acuh dengan tugas yang telah dikirimkan ke Grup WhatsApp, Orang tua hanya memikirkan pekerjaan dirumah tanpa memperhatikan tugas dan pelajaran yang telah diberikan Guru ke anaknya. Bahwa sebenarnya dengan Guru memberikan tugas atau Video ke Grup WhatsApp maka diharapkan mampu meningkatkan kemampuan dari siswanya. Akan tetapi, hal tersebut tidak dianggap penting oleh orang tua. Dengan tidak adanya peran dari orang tua dengan adanya pembelajaran daring ini maka anakanak tidak mengerjakan tugas yang telah diberikan oleh Guru dan anak hanya bermain-bermain dengan temannya di luar rumah sehingga kemampuan anak, baik 
PEDAGOGIKA

Volume 12 (Nomor 1) 2021

HaL. 32-52

kemampuan kognitif, afektif dan psikomtorik anak akan menurun.

Berbanding terbalik dengan Orang Tua yang memberikan perhatiannya kepada anaknya di masa pembelajaran daring ini. Orang tua yang memberikan perhatian kepada anaknya dengan selalu memberikan motivasi dan semangat kepada anaknya untuk belajar dan menyelesaikan tugas yang telah diberikan oleh Guru di Grup Whatsapp walaupun hanya sebentar, yang penting anak mau untuk belajar. Dengan pemberian motivasi dan semangat ke siswa maka, siswa akan mau belajar, sehingga kemampuannya, baik kognitif, afektif dan psikomotorik anak akan tetap berkembang sesuai dengan kondisi dari anaknya. Hal ini sesuai dengan pepatah "Setajam-tajamnya pisau kalau tidak diasah juga maka kan tumpul juga suatu saat nanti”. Yang artinya Sepandai-pandainya orang apabila tidak diasah atau belajar makan akan bodoh. Begitu juga dalam hal pembelajaran daring ini, karena terlalu lama libur maka anak akan malas belajar apabila tidak ada motivasi dari Orang Tua sehingga lupa dengan pembelajaran yang sudah pernah pernah dipelajari. Maka dalam hal itu, Orang tua harus selalu mengasah kemampuan yang dimiliki siswa dengan memberikan motivasi sehingga kemampuan anak akan berkembang dengan baik

khususnya yang berkaitan dengan kemampuan hasil belajar siswa.

Pada saat pembelajaran daring yang dilaksanakan ini hanya sedikit orang tua yang memberikan perhatian kepada anaknya mengenai tugas yang telah diberikan oleh Guru. Orang tua yang memberikan perhatian kepada anaknya yaitu kebanyakan orang tua yang bekerja di rumah dan orang tua yang menganggap penting arti pendidikan bagi anaknya. Sedangkan orang tua yang bekerja di luar lebih cuek dengan proses pembelajaran daring yang dilaksanakan, sehingga anak bertingkah sesuka hatinya bahkan sampai membiarkan anaknya untuk bermain game di handphone.

Adanya peran orang tua dalam pembelajaran Daring ini bisa membantu hasil belajar siswa, khususnya yang berkaitan dengan hasil belajar siswa dalam ranah afektif dan psikomotori peserta didik, karena dengan adanya motivasi dari orang tua kepada anaknya untuk menyelesaikan tugas baik itu tugas untuk membuat poster atau menggambar dan yang lainnya. Dengan melihat bagaimana orang tua membimbing menyelesaikan tugas dengan cara kreatif orang tua sendiri. Dan uga dapat meningkatkan kecakapan berfikir rasional peserta didik, yaitu meliputi peserta didik yang belajar mandiri melaui TV edukasi 
atau juga melaui Whatsapp group merupakan bentuk kecakapan peserta didik dimana peserta didik dapat menggali dan mengolah informasi yang di dapat, serta dapat menyelesaikan informasi tersebut, berupa tugas yang telah diberikan oleh guru. Kecakapan personal dapat melatih peserta didik untuk kreatif dalam menyelesaikan suatu permasalahan. (Ahsani \& Mulyani, 2020). Maka kemampuan psikomotorik anak juga akan tetap berkembang. Begitupun juga yang berkaitan dengan ranah afektif siswa, apabila orang tua memiliki sifat yang sekiranya baik untuk di tiru oleh anak, maka anak juga akan memiliki sifat yang baik pula, dilihat dari bagaimana sifat orang tuanya untuk menyelesaikan tugasnya sehari-hari apakah bisa menyelesaikan secara tepat waktu dan cepat atau malahan malas-malasan dalam menyelesaikan tugas. Selain hasil belajar afektif adan psikomotorik bisa berkembang, hasil belajar siswa yang berkaitan dengan ranah kognitif juga tetap bisa berkembang, akan tetapi tidak se optimal dengan pembelajaran tatap muka di sekolahan (dikelas), hal ini dikarenakan terkadang Guru hanya memberikan tugas untuk siswanya tanpa menjelaskan materinya sehingga untuk membimbing anaknya menyelesaikan tugas orang tua juga kesulitan, dan terkadang walaupun Guru sudah mengirimkan Video yang berkaitan dengan materi yang akan dipelajari, orang tua tidak paham akan materi yang telah diberikan oleh Guru, sehingga orang tua masih kesulitan dalam mengajari anak mengenai materi yang telah diberikan oleh Guru.

\section{Pembahasan}

\section{A. Peran Orang Tua}

Abu Ahmadi (2004 : 43) "peran orang tua merupakan suatu hal yang kompleks penghargaan manusia mengenai cara setiap individu untuk bersikap, yang memiliki tanggung jawab dalam keluarga". Dalam hal ini khususnya berhubungan dengan perang orang tua terhadap anaknya yang berkaitan dalam dunia pendidikan, keteladanan, dan kreatif sehingga nantinya dalam diri setiap anak akan timbul semangat hidup dalam rangka untuk pencapaian keselarasan hidup di dunia. Jadi, lingkungan keluarga terutama dengan orang tua yang sangat berperan penting karena dari orang tua lah yang secara langsung atau tidak langsung berhubungan erat dengan kehidupan sehari-hari anak, sehingga segala ucapan, tingkah laku dan sikap dari orang tua harus baik untuk ditiru oleh anak.

Dalam sebuah keluarga orang tua adalah pendidik yang pertama dan utama. Keutamaan Orang tua dalam hal ini yaitu 
sebagai petunjuk jalan, memberikan bimbingan pada anak dan juga orang tua adalah sebagai teladan bagi anak-anaknya. Oleh karena itu, orang tua dituntut untuk mampu mengarahkan, menuntun dan membimbing anaknya. Sebuah keluarga yang memiliki kedudukan utama adalah orang tua, hal ini karena dari keluargalah peran orang tua sebagai pendidik yang pertama bagi anak-anaknya untuk dapat memberikan pengetahuan secara global yaitu pengetahuan umum dan khusus.

Pengaruh peran orang tua sangat dipengaruhi oleh perannya dalam keluarga dan kesibukannya. Apabila seorang Ibu yang sibuk dengan pekerjaannya maka akan berbeda dengan peran ibu yang berkonsentrasi penuh sebagai orang tua untuk mengurus rumah tangganya. Perang orang tua juga dapat ditentukan melalui kepribadiannya. (Astuti, 2013).

Orang tua sebagai seseorang yang pertama dan utama dalam proses pendidikan anak mempunyai 3 peran dalam prestasi belajar anak, yaitu:

1. Memberikan kesempatan kepada anak yang sebaik-baiknya untuk dapat menemukan minat, bakat, serta kecakapan lainnya yang dimilikinya dan mendorong setiap anak agar mampu untuk meminta bimbingan dan nasehat kepada Guru.
2. Memberikan informasi yang penting dan releven sesuai dengan bakat dan minat yang dimiliki oleh anak.

3. Menyediakan fasilitas dan sarana prasarana untuk belajar dan untuk membantu dalam menghadapi kesulitan yang dirasakan dalam proses belajarnya.

Secara rinci dan luas perang orang tua dalam mendukung prestasi hasil belajar anak, yaitu:

1. Pengasuh dan pendidik

Selain sebagai pengasuh, orang tua juga memiliki peran sebagai pendidik yaitu dengan melatih keterampilan yang dimiliki oleh anak terutama yang berkaitan dengan sikap mental anak. Maka dalam hal ini, orang tua harus bisa untuk bertanggung jawab dalam rangka untuk menemukan bakat dan minat yang dimiliki oleh anak, sehingga anak dapat dididik dan diasuh baik oleh orang tua ataupun Guru sesuai dengan bakat dan minat yang dimiliki oleh anak, sehingga anak dapat memiliki dan meningkatkan prestasi belajarnya secara optimal.

2. Pembimbing

Bimbingan adalah semua kegiatan yang dilaksanakan oleh seseorang untuk memberikan bantuan kepada orang lain yang sedang mengalami 
kesusahan, sehingga orang tersebut dapat mengatasi permasalahan dengan penuh kesabaran. Orang tua harus senantiasa dan selalu memberikan bimbingan kepada anaknya secara berkelanjutan, karena anak belajar di sekolah hanya enam jam, dan bertemu gurunya hanya 2 sampai dengan 3 jam. Oleh karena itu bimbingan atau motivasi belajar yang berasal dari orang tua sangatlah berperan penting dalam meningkatkan prestasi belajar anak.

3. Motivator

Orang tua harus mampu untuk memberikan dorongan mengenai pentingnya belajar dalam rangka untuk meningkatkan prestasi belajar anak, sehingga anak akan merasa bahwa apa yang dianjurkan atau disuruh oleh orang tua itu sangat penting dan dibutuhkan. Dalam hal ini, orang tua harus mampu menjadi seorang motivator belajar untuk anak. Hal tersebut dapat dilakukan dengan cara membimbing anak untuk belajar dengan rasa kasih sayang, dan serta mampu untuk menciptakan suasana belajar di rumah. Suasana belajar di rumah dapat dilakukan dengan meminimalisir kebiasaan yang sekiranya kurang bermanfaat yang sering dilaksanakan di rumah, seperti menonton TV. Dengan tingginya motivasi belajar yang diberikan oleh orang tua maka semakin tinggi pula kemungkinan anak untuk bisa memperoleh prestasi belajar yang lebih maksimal lagi.

4. Fasilitator

Dalam proses belajar mengajar orang tua harus menyediakan berbagai fasilitas atau sara prasarana dalam proses belajar seperti media, alat peraga, dalam rangka untuk menunjang program belajar anak. Orang tua sebagai fasilitator juga bisa mempengaruhi tingkat prestasi yang dicapai oleh anak. Fasilitas yang telah diberikan oleh orang tua kepada anak selain media dapat berupa membiayai anak untuk bersekolah (Afni \& Jumahir, 2020).

\section{B. Hasil Belajar Siswa}

Hasil belajar adalah tolak ukur yang digunakan dalam rangka untuk menentukan tingkat keberhasilan belajar siswa dalam kemampuannya untuk mengetahui dan memahami dari suatu mata pelajaran yang telah dipelajarinya, serta adanya perubahanperubahan yang terjadi pada diri setiap siswa, baik yang berkaitan dengan aspek kognitif, afektif , psikomotorik sebagai hasil dari adanya kegiatan belajar mengajar. 
Hasil belajar juga dapat diartikan sebagai perubahan tingkah laku dari yang awalnya tidak bisa akhirnya menjadi bisa, dari yang belum tahu menjadi tahu. (Warti, 2018).

\section{Berdasarkan teori Taksonomi}

Bloom indikator hasil belajar dalam rangka studi dicapai melalui tiga kategori ranah, antara lain:

\section{(1) Ranah Kognitif,} berkenaan dengan hasil belajar intelektual yang terdiri dari 6 aspek yaitu pengetahuan, pemahaman, penerapan, analisis, sintesis dan penilaian. (2) Ranah Afektif, berkenaan dengan sikap dan nilai. Ranah afektif meliputi lima jenjang kemampuan yaitu menerima, menjawab atau reaksi, menilai, organisasi dan karakterisasi dengan suatu nilai atau kompleks nilai. (3) Ranah Psikomotorik, meliputi keterampilan motorik, manipulasi bendabenda, koordinasi neuromuscular (menghubungkan, mengamati). (Egziabher \& Edwards, 2013).
Faktor-faktor yang mempengaruhi hasil belajar siswa ada banyak sekali jenisnya, yang dapat digolongkan menjadi 2 faktor, yaitu:

1. Faktor Internal

Faktor Internal yaitu faktor yang terdapat dalam diri setiap individu itu sendiri dalam melakukan proses belajar, yang termasuk dalam faktor internal yaitu:

a. Faktor Jasmaniah (faktor yang berkaitan dengan kondisi dalam diri setiap individu), Contohnya yaitu kesehatan.

b. Faktor Psikologis (faktor yang berkaitan dengan kondisi psikis dari setiap individu), Contohnya intelegensi, perhatian, minat, bakat, motif, dan kematangan.

c. Faktor Kelelahan.

\section{Faktor Eksternal}

a. Faktor Keluarga, contohnya: cara orang tua dalam mendidik anaknya, relasi atau hubungan antar anggota keluarga, suasana dalam rumah, keadaan ekonomi keluarga, pengertian dari orang tua dan latar belakang kebudayaan masingmasing.

b. Faktor sekolah, contohnya: metode dalam proses belajar mengajar, kurikulum, relasi atau hubungan 
antara guru dengan siswa, relasi atau hubungan antara siswa dengan siswa, disiplin sekolah, alat pelajaran, waktu sekolah, standar pelajaran di atas ukuran, keadaan guru, metode belajar, tugas rumah.

c. Faktor Masyarakat, contohnya: kegiatan siswa dalam kehidupan masyarakat, media massa, teman bergaul atau bermain, bentuk kehidupan dalam masyarakat di sekitar tempat tinggalnya. (Astuti, 2013).

\section{Pembelajaran Daring Di Masa Pandemi Covid-19}

Semakin meluasnya kasus pandemi Corona Virus Disease (Covid 19) sejak akhir tahun 2019 sampai dengan saat ini maka mengharuskan untuk seluruh proses kegiatan belajar mengajar bagi peserta didik untuk sementara waktu ini dilakukan dengan cara belajar dari rumah. Hal ini sangat perlu dilaksanakan karena untuk mencegah penularan virus Corona. Dalam rangka untuk mengisi kegiatan belajar mengajar yang dilaksanakan di rumah yang memang harus diselesaikan pada tahun pelajaran ini, maka akhirnya pemerintah mengambil keputusan agar seluruh pembelajaran dilakukan melalui metode pembelajaran jarak jauh dengan menggunakan media daring (dalam jaringan), baik itu menggunakan ponsel, PC ataupun laptop. Penggunaan media daring dalam pelaksanaan pembelajaran di masa pandemi ini dirasa sebagai langkah selektif yang sangat efektif dalam rangka untuk mencegah dan mengurangi penyebaran virus di lingkungan pendidikan.

Penilaian terhadap hasil kerja siswa tetap perlu diberikan oleh Guru agar tujuan pembelajaran itu dapat tercapai. Salah satu tujuan pembelajaran daring ini yang dapat dicapai adalah berupa pencapaian kompetensi peserta didik yang sering disebut dengan sebutan $4 \mathrm{C}$, yaitu Critical Thinking (berpikir kritis) yang mengarahkan peserta didik agar dapat menyelesaikan masalah (Problem Solving), Creativity Thinking (Berfikir Kreatif), Collaboration (bekerja sama atau berkolaborasi), dan Communication (Berkomunikasi).

Pandemi Covid 19 ini bisa menjadi percobaan untuk mengubah pembelajaran tekstual menjadi kontekstual. Pembelajaran kontekstual adalah konsep belajar mengajar yang mengaitkan antara materi pelajaran dengan kehidupan sehari-hari peserta didik. Siswa diharapkan mampu untuk menemukan dan mengembangkan pengetahuan dan keterampilan barunya sesuai dengan pengetahuan yang telah mereka miliki. Dengan demikian, siswa 
PEDAGOGIKA

Volume 12 (Nomor 1) 2021

HaL. 32-52

akan lebih memahami dan lebih memaknai pengetahuannya. (Anugrah, 2020) . Salah satu pemanfaatan pembelajaran daring adalah dengan menggunakan aplikasi WhatsApp (WA), Guru membuat Grup WA untuk melaksanakan komunikasi dengan Orang Tua murid.

\section{Gambar 1. Logo WhatsApp}

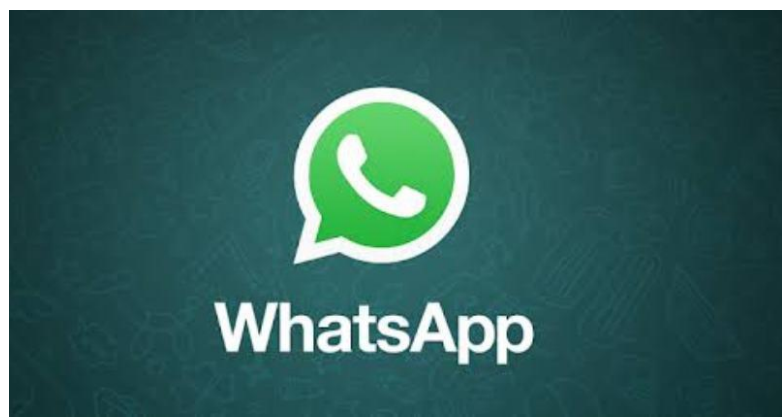

WhatsApp adalah sebuah aplikasi yang dapat dugunakan untuk chatting yang biasanya tersedia di Smartphone yang dapat memungkinkan penggunanya untuk berbagi gambar dan pesan. WhatsApp adalah salah satu aplikasi pesan seluler yang memungkinkan untuk bertukar pesan tanpa harus membayar SMS, ini dikarenakan aplikasi WhatsApp memakai paket data internet. (Elianur, 2017). WhatsApp memiliki beberapa fitur yang dapat memudahkan penggunanya dalam melakukan komunikasi dengan orang lain. Fitur tersebut diantaranya yaitu:

\section{Chat Grup}

Dalam salah satu fitur WhatsApp yaitu Chat Grup, pengguna WhatsApp dapat membagikan pesan, foto dan video ke banyak orang sekaligus dalam satu waktu dan satu tempat. Pengguna Chat Grup dalam WhatsApp ini juga dapat membisukan dan menyesuaikan pemberitahuan, dan masih banyak lagi. Dengan menggunakan fitur ini, maka pengguna WhatsApp dapat tetap terhubung dengan peserta didik yang ada dirumah melaui smartphone yang dimiliki oleh orang tuanya.

\section{Gambar 2. Chat Grup WhatsApp}

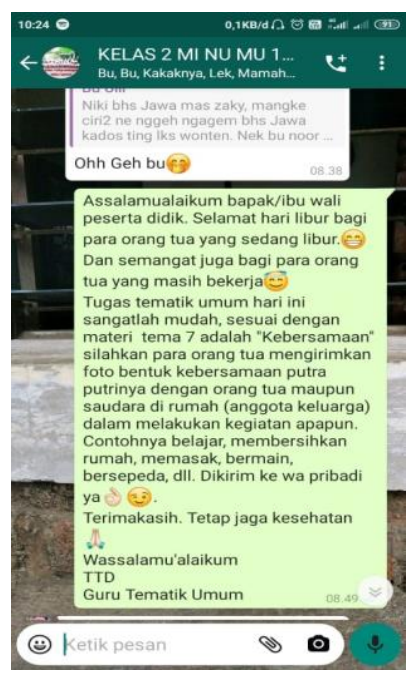

2. WhatsApp di Web dan Desktop

Dengan penggunaan fitur ini, maka pengguna WhatsApp dapat dengan melakukan komunikasi melalui komputer atau laptop sehingga dapat melakukan chat atau komunikasi dengan lancar dan dapat melalui perangkat apapun dengan nyaman. 
Gambar 3. WhatsApp Web

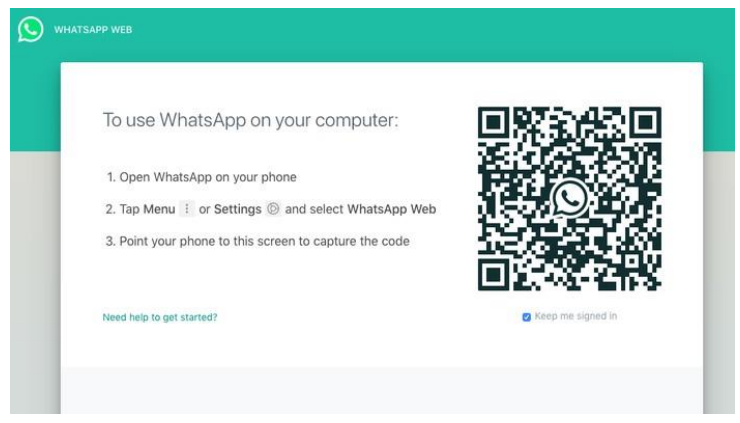

3. Panggilan Suara dan Video WhatsApp Dengan penggunaan fitur ini, maka para penggunaan WhatsApp dapat berbicara dan berkomunikasi dengan siapapun secara gratis dan bahkan bisa juga berkomunikasi dengan orang yang sedang berada di Negara lain. Melalui fitur panggilan Video, maka pengguna dapat melakukan percakapan dengan cara tatap muka apabila dengan suara atau teks itu tidak cukup. Panggilan suara dan video ini menggunakan koneksi internet telepon, bukan dengan pulsa panggilan seluler.

\section{Enkripsi end-to-end}

Dengan adanya fitur ini, maka pesan yang sudah dikirim hanya bisa dilihat oleh orang terdekat atau dengan orang yang sedang melakukan komunikasi dengan pengguna tersebut. Tidak ada orang ketiga yang bisa mengetahuinya, walaupun juga menggunakan WhatsApp.

5. Foto dan Video
Dengan adanya fitur ini, maka pengguna dapat mengirim foto dan video di WhatsApp dengan cepat walaupun sedang dalam kondisi koneksi lambat. Dan juga pengguna dapat menangkap atau mengambil momen berupa foto atau video yang penting dengan kamera yang sudah ada dari aplikasi.

6. Pesan Suara

Dengan adanya fitur ini, maka pengguna dapat mengatakan secara langsung semua hal hanya dengan cara satu ketukan saja. Pesan suara bukan hanya bisa digunakan untuk menyapa saja akan tetapi, juga dapat digunakan untuk bercerita yang panjang.

7. Dokumen

Dengan adanya fitur ini, untuk pelajar, mahasiswa dan juga pekerja kantor dapat mengirim PDF berupa dokumen, spreadsheet, slideshow, dan masih banyak lagi. Fitur ini dapat memudahkan pengiriman file tanpa harus menggunakan e-mail atau aplikasi lain yang dapat mengirim file. Maksimal file yang bisa dikirim melalui aplikasi WhatsApp ukurannya mencapai 100 MB. (Pangestika, 2018). Kelebihan dari aplikasi WhatsApp , antara lain: Dapat menghemat penggunaan kertas karena siswa tidak harus mencetak tugas- 
tugas yang telah diberikan, maka pembelajaran dapat bisa lebih rileks dilakukan di ruangan dan waktu belajar yang lebih banyak, tempat promosi, memperluas jaringan pertemanan, sebagai tempat untuk mencari informasi yang bermanfaat, tempat saling berbagi foto dan dokumen. (Pranajaya, 2018). Kekurangan dari aplikasi WhatsApp, antara lain: susah bersosialisasi dengan orang sekitar (dikarenakan penggunaan sosial media menjadi malas dalam belajar dan berkomunikasi secara nyata). Dengan penggunaan sosial media dalam pembelajaran maka akan membuat seseorang lebih mementingkan dirinya sendiri (tidak sadar dengan lingkungan disekitarnya, karena pengguna menghabiskan waktu dengan bermain internet). (Munirah, 2015).

\section{SIMPULAN}

Dari penjelasan diatas, maka dapat disimpulkan bahwa orang tua sangat berperan penting terhadap hasil belajar siswa dalam pembelajaran daring di masa pandemi Covid-19. Perang Guru dalam proses belajar mengajar yang dilaksanakan di sekolah memang sangatlah penting, akan tetapi hasil belajar siswa apabila tidak didukung dengan adanya peran orang tua maka hasil belajar siswa bisa saja tidak meningkat, Orang tua yang mempunyai tanggung jawab untuk mengasuh, mendidik, membimbing, memotivasi dan fasilitator sejak dari awal merasakan dunia sampai akhir hidup sangatlah penting. Dengan adanya tanggung jawab yang dilakukan oleh orang tua untuk anaknya maka dapat mempengaruhi hasil belajar dari anak itu sendiri.

Dengan adanya perhatian dari orang tua, khususnya pada saat proses pembelajaran daring ini, maka peran dari orang tua sangalah penting. Kemampuan yang dimiliki anak pada saat sedang bertatap muka dengan Guru dan sedang belajar dirumah maka tidak akan turun bahkan hilang, karena dengan adanya perang orang tua untuk selalu mendampingi anak dalam menyelesaikan tugas maka kemampuan yang dimiliki anak tetap berkembang walaupun tidak sesignifikan pada saat sekolah di kelas.

Dalam pelaksanaan pembelajaran daring ini upaya yang dapat dilakukan orang tua adalah dengan selalu memberikan motivasi dan semangat. Orang Tua harus selalu memberikan semangat dan motivasi kepada anaknya, agar anak tidak merasa terbebani dengan tugas yang telah diberikan oleh Guru. Anak akan memiliki semangat yang tinggi untuk mengerjakan tugas yang diberikan oleh Guru apabila anak selalu disemangati dan dimotivasi oleh orang tua 
untuk selalu mengerjakan tugas dari Guru yang telah dikirim melalui Grup WA kelas. Sebab, apabila anak tidak didampingi atau diingatkan mengenai bahwa mereka itu bukan sedang liburan akan tetapi sedang belajar di rumah maka, anak akan bertingkah sesuai keinginannya tanpa belajar sekalipun. Dengan adanya motivasi dan semangat yang selalu diberikan kepada anaknya maka hasil belajar anak, baik dilihat dari kemampuan kognitif, afektif ataupun psikomotorik yang dimiliki anak akan tetap berkembang sesuai dengan tahapan usianya.

\section{REFERENSI}

Afni, N., \& Jumahir, J. (2020). Peranan Orang Tua Dalam Meningkatkan Prestasi Belajar Anak. Musawa: Journal for Gender Studies, 12(1), 108-139.

https://doi.org/10.24239/msw.v12i1.5 91

Ahsani, E. L. F., \& Mulyani, S. E. (2020). The Implementation of Distance Learning Based E-Learning for Developing Student's Life Skills. Didaktika: Jurnal Pendidikan Sekolah Dasar, 3(2), 115-120.

Ahsani, E. L. F., \& Ningsih, A. (2020). Pengaruh Pembelajaran Melalui Program TVRI Terhadap Aspek
Psikomotorik Siswa SD di Masa Pandemi Covid-19. AR-RIAYAH : Jurnal Pendidikan Dasar, 4(2), 145. https://doi.org/10.29240/jpd.v4i2.1594 Anugrah, D. (2020). Dinamika Pembelajaran Daring Di Tengah Pandemi Covid-19. Berita Magelang. http://beritamagelang.id/kolom/dinami ka-pembelajaran-daring-di-tengahpandemi-covid-19

Astuti, D. (2013). Analisis Peran Orang Tua dalam Meningkatkan Hasil Belajar Siswa Kelas X SMK Muhammadyah Pontianak. Journal Untan, 4(1), 64-71. http://jurnal.untan.ac.id/index.php/JPS H/article/view/22027/17653

Egziabher, T. B. G., \& Edwards, S. (2013). Hubungan Antara Perhatian Orang Tua Dengan Hasil Belajar Siswa Kelas V SDN 64/1 Muara Bulian. Africa's Potential for the Ecological Intensification of Agriculture, 53(9), 1689-1699.

Elianur, C. (2017). Pemanfaatan Aplikasi Whatsapp Sebagai Sarana Diskusi Antara Pengawas Dan Guru Pendidikan Agama Islam. Jurnal AsSalam, 1(2), 1-14.

Indonesia, C. (2020). Update Corona 10 Mei: 14.032 positif, 2.698 sembuh. https://www.cnnindonesia.com/nasion 
al/20200509195317-20-

501653/update-corona-10-mei-14032-

positif-2698-sembuh.

Miranti, I., Dwiastuty, N., Studi, P., \& Bahasa, P. (2017). Peran Serta Orang Tua Dalam Meningkatkan Hasil Belajar Bahasa Inggris Siswa. Jurnal Ilmiah Kependidikan, 4(2), 119-124.

Munirah. (2015). Penggunaan Aplikasi WhatsApp Pada Pembelajaran Menulis Paragraf Narasi Bahasa Indonesia. Kongres Bangsa Indonesia. Makassar: Universitas

Muhammadiyah Makassar.

Nurlaeli, D. R. dan N. N. (2020). Kelekatan (Attachment) Ibu - Anak Di Tengah COVID-19. Program Studi Studi Ilmu Kesejahteraan Sosial, Fakultas Ilmu Sosial Dan Ilmu Politik. Universitas Padjajaran.

Pangestika, N. L. (2018). Pengaruh pemanfaatan media sosial whatsapp terhadap penyebaran informasi pembelajaran di SMA negeri 5 depok. $1-71$.

http://repository.uinjkt.ac.id/dspace/bit stream/123456789/41759/1/NUR LIA

PANGESTIKA-FITK.pdf

Pemerintah pusat . (2020). bekerja dari rumah (Work From Home) dari sudut pandang unit kepatuhan internal . Direktorat Jenderal
Kekayaan Negara kementrian keuangan https://www.djkn.kemenkeu.go.id/a rtikel/baca/13014/BekerjadariRumah-Work-From-HomeDari-Sudut-Pandang-UnitKepatuhan-Internal.html. Diakses pada 08 Mei 2020.

pemerintah Pusat . (2020, maret). Surat edaran mendikbud no 4 tahun 2020 tentang pelaksanaan kebijakan pendidikan dalam masa darurat Covid-19. Retrieved from Pusat Pendidikan dan Pelatihan Pegawai KEMENDIKBUD

https://pusdiklat.kemdikbud.go.id/s urat-edaran-mendikbud-no-4-tahun2020tentang-pelaksanaan-

kebijakan-pendidikan-dalam-masadarurat-penyebarancorona-virusdisease-covid-1-9/. Diakses pada 08 Mei 2020.

pusat, P. (2018, agustus). Undang-undang nomor 6 tahun 2018 . Retrieved from JDIH BPK database peraturan https://peraturan.bpk.go.id/Home/D etails/90037/uuno-6-tahun-2018. Diakses pada 08 Mei 2020. 
pusat, P. (2020 , februari rabu). lahkah dan upaya pemerintah indonesia dalam menangani dan menghadapi virus novel corona 2019. Retrieved from kedutaan besar republik indonesia pretoria, Afrika Selatan: https://kemlu.go.id/pretoria/id/news 14771/langkah-dan-upaya-

pemerintahindonesia-dalam$\underline{\text { menangani-dan-menghadapi-virus- }}$ novel-corona-2019-n-cov. Diakses pada 08 Mei 2020.

pusat, P. (2020, April senin). keputusan presiden (KEPRES) NOMOR 12 TAHUN 2020. Retrieved from JDIH BPK Database peraturan : https://peraturan.bpk.go.id/Home/D etails/135718/keppres-no-12-tahun2020. Diakses pada 08 Mei 2020.

Pranajaya, W. rendra. (2018). Pemanfaatan
Aplikasi Whatsapp ( Wa ). 14(1), 5967.

RI, K. (n.d.). Sistem Pendidikan Nasional.

Setiawan, H. (2020). Peran Orang Tua Dalam Pembelajaran Daring. Suara Merdeka.

https://www.suaramerdeka.com/news/ opini/222555-peran-orang-tua-dalampembelajaran-daring

Shiyana. (2014). Materi Ilmu Pendidikan dan Psikologi kelas XII. MA MU'ALLIMAT NU KUDUS.

Warti, E. (2018). Pengaruh Motivasi Belajar Siswa terhadap Hasil Belajar Matematika Siswa di SD Angkasa 10 Halim Perdana Kusuma Jakarta Timur. Mosharafa: Jurnal Pendidikan Matematika, 5(2), 177-185. https://doi.org/10.31980/mosharafa.v5 i2.273 